Techniques \& Culture

$10 \mid 1988$

D'autres idées pour observer

\title{
Des idées pour observer
}

\section{François Sigaut}

\section{(2) OpenEdition}

Journals

Édition électronique

URL : https://journals.openedition.org/tc/832

DOI : $10.4000 /$ tc. 832

ISSN : 1952-420X

\section{Éditeur}

Éditions de l'EHESS

\section{Édition imprimée}

Date de publication : 1 mars 1988

ISSN : 0248-6016

\section{Référence électronique}

François Sigaut, «Des idées pour observer », Techniques \& Culture [En ligne], 10 | 1988, mis en ligne le 23 janvier 2006, consulté le 29 septembre 2022. URL : http://journals.openedition.org/tc/832 ; DOI https://doi.org/10.4000/tc.832

Ce document a été généré automatiquement le 29 septembre 2022

Tous droits réservés 


\section{Des idées pour observer}

François Sigaut 